\title{
The politics of making and un-making (sustainable) futures
}

\author{
Henrike Knappe ${ }^{1} \cdot$ Anne-Katrin Holfelder $^{1} \cdot$ David Löw Beer $^{1} \cdot$ Patrizia Nanz $^{1}$
}

Published online: 27 February 2018

(c) Springer Japan KK, part of Springer Nature 2018

\begin{abstract}
Although the general goals of sustainability have become less controversial since the Brundtland report 1987, the concrete imperatives for action such as decarbonization or the preservation of biodiversity do not seem to be very effective in pushing social and political transformation processes (Miller et al. 2014). Making futures more sustainable is often discussed as a matter of technological, scientific or economic concern-futures have become depolitisized.
\end{abstract}

This special feature points to blind spots in the political and social dimensions of future making. It seeks to investigate the blockades and potentials of transformation processes that can be found on the level of concrete political and social practices. Future making can be divided into futures for the present, as concrete visions and plans that are made to facilitate decisions in the present or presents for the future, as images and knowledges that evolve in the present and affect the future in different ways. Futures for the present are built for example by presenting pathways for climate policy making (Beck and Mahony 2017) or by envisioning utopian technological futures. Presents for the future emerge for example from practices of political decision-making on nuclear waste disposal or public investments.

Thus, the proposed special feature wants to shed light on social and political practices that are making and un-making sustainable futures. Future practices, (i.e. the implicit or explicit building of relations and making of references to future situations and people) take place between the past, present and the future. They evolve in multiple interactions between the production, use and organization of knowledge about the future (Granjou et al. 2017), the structural

Henrike Knappe

Henrike.Knappe@iass-potsdam.de

Anne-Katrin Holfelder

Anne-Katrin.Holfelder@iass-potsdam.de

David Löw Beer

David.LoewBeer@iass-potsdam.de

1 Institute for Advanced Sustainability Studies (IASS),

Potsdam, Germany restrictions imposed on collective and individual actors dealing with the future (Sardar 1999), the impulses and necessities of change, the hopes and plural imaginaries for the future (see Leccardi 2012, Milkoreit 2016, Appadurai 2013) and ethical principles pointing towards just and 'good' futures (Adam and Groves 2007; Groves 2014).

Building on different debates in Anthropology, Educational sciences, Economics, Environmental Humanities, History, Political Economy, Political science, Science and Technology Studies and Sociology, we aim to critically and explicitly analyse the pitfalls and problems of future practices and develop a more nuanced understanding of sustainable future practices and their enabling conditions.

Thus, the special feature invites contributions to the following topics:

1. Presents for the future: analyses of future practices in policy fields and institutions concerning sustainability related topics (such as energy transition, sustainable development, green innovations, international climate policies).

2. Futures for the present: critical engagements with alternatives and visions in future-making in sustainable transformation initiatives, social movements, educational practices and programmes or investment strategies.

\section{Deadlines, submission, and review process}

Authors are encouraged to submit extended abstracts (maximum 500 words) to the editors of the SF. Upon acceptance, authors will be invited to submit full-length manuscripts through the journal's electronic editorial management system, keeping in mind publisher formatting guidelines and length requirements. At this point, authors should state if they are submitting their work to be considered for the "The politics of making and un-making (sustainable) futures"SF. Papers will go through a blind review process. Submit abstracts to 


\section{Author's guidelines}

http://www.springer.com/environment/environmen tal+management/journal/11625?detailsPage $=$ pl tci_728046

\section{Submission guidelines}

For submission through EM system, please register in EM system (below link) and submit your article selecting the $\mathrm{SF}$ title. You can see author tutorial on right side of the registration page.

http://www.editorialmanager.com/sust/mainpage.html

\section{Important dates and deadlines}

March 20, 2018: submission of extended abstracts (maximum 500 words) to the editors.

June 30, 2018: submission of full papers.

Mid 2019: expected publication of the SF.

\section{References}

Adam B, Groves C (2007) Future matters. Action, knowledge, ethics. Brill, Leiden (supplements to the study of time)

Appadurai A (2013) The future as cultural fact. Essays on the global condition. Verso (politics/anthropology), London

Beck S, Mahony M (2017) The IPCC and the politics of anticipation. Nat Clim Change 7(5):311-313

Granjou C, Walker J, Salazar JF (2017) Guest editorial to the special feature 'Politics of Anticipation: on knowing and governing environmental futures'. Futures 92:1-4

Groves C (2014) Care, uncertainty and intergenerational ethics. Palgrave Macmillan, Basingstoke

Leccardi C (2012) Young people's representations of the future and the acceleration of time. A generational approach. Diskurs Kindheitsund Jugendforschung 7(1):59-73

Milkoreit M (2016) The promise of climate fiction-imagination, storytelling and the politics of the future. In: Wapner P, Elver H (eds) Reimagining climate change. Routledge, London

Sardar Z (ed) (1999) Rescuing all our futures. The future of futures studies. Praeger (Praeger studies on the 21st century), Westport

Miller TR, Wiek A, Sarewitz D et al (2014) The future of sustainability science: a solutions-oriented research agenda. Sustain Sci 9(2):239-246 